| GOSOS | Gaziosmanpaşa Üniversitesi Sosyal Bilimler Araştırmaları Dergisi/GOSOS

Gaziosmanpasa University Social Sciences Researches Journal

(Yaz 2015) 10/1: 167-184/(Summer 2015) 10/1: 167-184

\title{
Toplumsal Cinsiyet Bağlamında Televizyon Reklamlarında Geleneksel Kadın Tiplemesi: Deterjan Reklamlarında Kadının Temsili
}

\section{Ömer Büstan 1}

\begin{abstract}
Medya giderek artan bir yoğunlukta, gündelik hayatın vazgeçilmez parçası haline gelmeye başlamıştır. Özellikle televizyon hemen her ailenin evinde bulunan ve sürekli kullanılan bir araç olarak oldukça önem kazanmıştır. Bunun sonucu olarak da televizyon yayıncılı̆̆

$\ddot{O} z$ anlayışı içerisin de yer alan ürün ve hizmetlere olan ilginin arttırlmasına yönelik televizyon reklamlarının sayısı gün geçtikçe artmıştır. Bu amaçla, reklam yayınları yapılmaktadır. İzleyicin dikkatini çekmek için de reklamlarda genellikle kadınlara rol verilmektedir. Bu çalışmada toplumsal cinsiyet bağlamında kadının medyadaki (reklamlarda) temsili ele alınmış ve geleneksel kadın temsili örnek deterjan reklamları üzerinden irdelenmeye çalışılmıştır.
\end{abstract}

Anahtar Kelimeler: Toplumsal cinsiyet, toplumsal rol, reklamda kadın temsilleri

\section{Traditional Woman Character (typing) in Tv Commercial in the Context of Gender. Representation of Women in Detergent Advertisements (ads)}

\footnotetext{
There is an increasing density in media. It has started to be an indispensable part of daily life. Especially television has gained importance as a tool used continually and found in almost every family homes. As a result, one of the importance functions of television in the television broadcasting concept is to provide an interest in the services and products available on the market. For this purpose, ads broadcast is made. Women are generally used in ads in order to attract television viewers' attention. In this study, the representation of woman in media has been dealt with in the context of social gender and also the representation of traditional woman has been studied to examine via sample detergent ads.
}

Keywords: Social gender, social role, the representation of women in ads

\section{GİRIŞ}

Medya giderek artan bir yoğunlukta, gündelik hayatın vazgeçilmez parçası haline gelmeye başlamıştır. Özellikle televizyon hemen her ailenin evinde bulunan ve sürekli kullanılan bir araç olarak oldukça önem kazanmıştır. Bu nedenle, televizyon

\footnotetext{
${ }^{1}$ Yüksek Lisans Öğrencisi, Atatürk Üniversitesi, Sağllk Kurumları İşletmeciliği ve Yönetim
} Anabilim Dalı, e-mail: omerbustan@hotmail.com 
popüler kültürü oluşturma konusunda diğer geleneksel iletişim araçlarına göre daha etkin bir araçtır (Yılmaz, 2007: 1). Bu bağlamda kitle iletişim araçlarında özellikle televizyonda, geniş kitlelere verilmek istenen mesajlar en kısa zamanda ve etkin bir biçimde ulaştırılmaya çalışılır. Kitle iletişim araçları kişilerin duygu, düşünce, davranış ve inanç kalıpları üzerinde çok büyük bir güce sahiptir. Dolayısıyla bir ürünün tanıtımında dikkat çekici ve akılda kalıcı unsurlar kullanılmaktadır (Türkoğlu ve Alayoğlu, 2009: 511). Televizyonda reklamlar; mal ve hizmet tanitımının yanı sira bireysel ve toplumsal cinsiyet rollerinin kurulmasında etkin olan yeni eğilimleri de yansıtır (İmançer ve İmançer, 2006: 121).

Pazarlama faaliyetinin en önemli unsuru olarak değerlendirilen reklamlar, insanların sahip oldukları şeylerden daha fazlasını ve yenisini istemeyi sağlamak ve ekonomik, maddi olanakları ne olursa olsun, onları daha fazlasını istemeye özendirmektedir. Bunu yaparken de tanıttığı ürün ya da hizmete anlam yüklemesi kaçınılmazdır. Bu noktada reklamın bir imaj yaratması önem kazanmaktadır. Günümüzde kitle iletişim araçları bu imajı kadına ve erkeğe nasıl kadın ve erkek olması gerektiğine ilişkin rol modellerini sunarak göstermektedir. Bu bağlamda toplumsal cinsiyet rolleri içinde kadının nasıl ve hangi alanlarla ilgilenmesi gerektiği de reklamlar aracılığı ile içselleştirilmektedir (Karaca ve Papatya, 2011: 480).

Kadının reklamda gösteriliş biçimi göz önüne alındığında kadına bazı roller yüklenmiştir. Bu roller: geleneksel rollerdeki kadınlar, dekoratif kadınlar, geleneksel olmayan rollerdeki kadınlar, süper kadın rolünde olan kadınlar (Türkoğlu ve Alayoğlu, 2009: 515). Bu roller içinde ise kadın reklamda; Anne/Ev Kadını/Eş, Meslek Sahibi, Seks Objesi, Güzel ve Bakımlı, Doğal Kadın olarak temsil edilmektedir ( Çolakoğlu, 2011: 77).

$\mathrm{Bu}$ çalışmada toplumsal cinsiyet rollerine değinildikten sonra reklamlarda kadına yüklenen roller ve kadının temsil ediliş biçimleri ele alınmıştır. Bu çerçevede kadının 'geleneksel kadın' olarak kullanıldığı deterjan reklamı örneklerine yer verilmiştir. İncelen reklamlarda eleştirel söylem analizi kullanılmıştır.

\section{TOPLUMSAL CINSIYYET KAVRAMI VE ROLLERI}

Toplumsal cinsiyet, toplum tarafından dayatılan ve beklenilen, erkeklik ve kadınlıkla ilişkilendirilmiş sosyal ve kültürel normları içerir. Sosyalleşmeden ve sosyal bağlamdan çıkarılan kavramın toplumdaki yansıması kadına ve erkeğe atfedilen rollerden oluşur. 


\section{| ÖMER BÜSTAN}

Toplumsal cinsiyet, kadın ve erkeğin, içinde yaşanılan toplumun gelenek ve görenekleri çerçevesinde belirlenmiş sosyal rol ve sorumluluklarını ifade etmektedir. Buradaki cinsiyet kavramı, yalnızca kadınla erkeğe atfedilen cinsiyet kalplarına ve toplumun onlardan beklediği davranışlara işaret etmektedir (Mera, 2008: 19).

Toplumsal cinsiyet rollerinin oluşturulmasında etkili olan kimi süreçler bulunmaktadır. Biyolojik, sosyal ve tarihsel süreçler kişinin kadın ve erkek olarak içinde doğduğu topluma uyumlanması ve kendini olduğu kadar çevresini de anlamlandırmasını sağlar. Biyolojik süreç, anatomik yapıların farklılığına, hormonal dönüşümlerin ayrışmasına dayanır. Bu farklılıklara bağlı olarak kişi bedenini kadın ve erkek olarak tanımlar. Sosyal süreç, çevrenin belirlediği kadın ve erkek davranışları, duygu, değer ve düşünce beklentileri ile ilişkilidir. Kadın ve erkek olarak sosyalleşir, çevrenin kadın ve erkek rol beklentilerine göre koşullanırız. Tarihsel süreç ise kültürün ve aile tarihinin taşıyıp yinelediği kadın ve erkek olma davranış biçimleri ile ilintilidir (Yüksel, 2006: 116).

Ayrıca İmançer'e göre toplumsal cinsiyet rollerinin oluşmasında iki farklı yaklaşım söz konusudur. Birincisi 'biyolojik yaklaşım' ikincisi ise 'kültürel yaklaşımdır'. Biyolojik yaklaşım; kadın ve erkek arasındaki biyolojik özelliklerden kaynaklanan kapasite ve yetenek farklarının toplum içindeki çeşitli rolleri yerine getirmesindeki temel karakteristiklerdir. Kültürel yaklaşım ise, kadın ve erkek rollerinin toplumsal olarak belirlenmesidir (2006: 3-7).

Her iki cinse yüklenilen anlamlar kültürden ve toplumsal değişimlerden etkilenmektedir. Bu nedenle toplumsal cinsiyetin kadın ve erkeğe yüklediği roller toplumdan topluma ve dönemden döneme değişiklik göstermektedir. Toplumsal cinsiyet kadın ve erkeğin toplum içerisindeki konumlarını belirler ve sınırlarını çizer. Giyinme biçimleri, sahip olunan mal ve eşyaların biçimi ve rengi gibi özellikler toplumsal cinsiyeti ve konumu ortaya koymaktadır. Toplum içerisinde kabul gören davranış kalıpları ve cinslere atfedilen karakter özellikleri de toplumsal cinsiyete göre farklılaşmaktadır. Kadının itaatkâr, yumuşak başlı, sabırlı, becerikli ve anaç olması beklenirken; erkeklerin öz güvenli, sözünü dinleten ve iyi para kazanan biri olması beklenmektedir (Mera, 2008: 19).

II. TOPLUMSAL CİNSIYYET VE REKLAM İLIŞKİSİ 
Toplumsal cinsiyet, bir kadın ya da erkek olarak davranmayı öğrenmekten daha fazla bir şeyi ifade etmektedir. Gün boyu, binlerce önemsiz eylemde cinsiyet, toplumsal olarak yeniden üretilmekte ve yeniden oluşturulmaktadır. Toplumsal cinsiyet farklılı̆̆ı, sosyal yapılandırmanın bir sonucudur ve değiştirilebilmektedir. Zaman içerisinde değişen cinsiyet rolleri bunun bir göstergesidir. Toplumsal cinsiyet yaşamımızı şekillendirmekte ve nasıl davranmamız gerektiğini öğretmektedir. Sosyal çevre içerisinde öğrenilen roller tekrarlanan reklâmlar tarafından da pekiştirilmektedir. İzleyiciler reklâmdaki sembolik sunum alanını çözümlemekte ve farkında olmadan benimsemektedirler (Çolakoğlu ve Doğaner, 2008: 336).

Toplumsal cinsiyet rolleri; aile, arkadaş, iş ya da okul çevreleri içerisinde öğrenilmektedir. Bu noktada reklam iletişimi bu sosyal çevrelerde öğrenilen kalıp davranışları pekiştirir. Hem günlük yaşama ait değerleri, bilgi ve inanışları, tutum ve kanaatleri kodlar hem de ürünü satmaya çalışırken kültürel ve toplumsal değerlere de başvurur. Aile ve toplum içerisinde nasıl yemek yeneceği, uyunacağı, kadın ve erkeğin evde ve ev dışındaki davranış biçimleri reklam vasıtasıyla mevcut ya da olması istenen toplumsal cinsiyet modellerine uygun biçimde sunulmaktadır. Reklamlar, bireylerin içinde bulunduğu toplumsal yapının değer yargılarını, kalıplaşmış davranış biçimlerini ve cinsiyet rollerini sürekli farklı senaryolar kullanarak aktarmaktadırlar. Kadın cinsi için analık, hamaratlık, itaat; erkek cinsi içinse babalık, reislik, otorite gibi toplumun biçtiği ve beklediği kalıp davranış biçimleri reklam yoluyla sürekli olarak yeniden üretilir ve pekiştirilir (Meral, 2008: 20).

Kitle iletişim araçlarında, özellikle de televizyon reklamlarında, kadın ve erkek kimliklerinin nasıl olması gerektiği yolundaki mesajlar (yeniden) üretilmektedir. Kitle iletişim araçları, toplumsal idealleri yansıtan kurumlar olduklarından, bu araçların sosyal temsiller aracılığı ile yansıttıkları kadınla erkek tanımlamaları toplumsal gerçeklikle birebir örtüşmese de toplumun ulaşmak istediği idealleri ortaya koymaktadır. "İletişim endüstrisi belli kalıp yargılara dayalı olarak ürettiği imgelerle genel izleyici kitlesini ekran başına çekip kâr ederken, aynı zamanda bu izleyici kitlesinin toplumsal değer beklentisine de yanıt vermiş olmaktadır." Kitle iletişim araçları gerçekliği sunarken, onu olduğu gibi yansıtmamakta yeniden kurgulamaktadır. Ancak, kurgulama yapılırken seçilen imgeler gerçek dünyadan alındığından izleyicide birebir gerçekliği yansıtıyormuş gibi bir izlenim yaratılmaktadır (Demir, 2006: 290). 


\section{| ÖMER BÜSTAN}

Reklamlar, toplum içinde oluşan imgeleri yansıttıkları gibi, aynı zamanda biçimlendirmektedir. Televizyon bir iletişim aracı olarak, hem cinsiyet değerlerini hem de insanların hayat görüşünü etkilemektedir. “Örneğin; televizyon reklamlarında kadının seks objesi olarak gösterilmesi, toplumun bireyleri üzerindeki değerde kadını bu biçimde görmeye, ya da böyle düşünmeye iter. Kadın devamlı ev işlerinde ve mutfakta gösterilirse, toplumdaki düşünce bu defa kadını bu gözle düşünür. Ancak bu imajı değiştirip, kadın büyük bir ofiste toplantı salonunda kalabalık üyeler içinde başkanlık yaparken, erkek de önünde önlük, mutfakta ya da çocuğun altını değiştirirken daha sık biçimde izlenirse toplumun yargıları bundan böyle değişebilir." $\mathrm{Bu}$ bağlamda televizyon reklamlarının kitleyi ne denli etkilediği görülebilmektedir (Demir, 2006: 293).

\section{REKLAMLARDA KADINA YÜKLENEN ROLLER VE KADININ}

\section{TEMSİL EDİLİŞ BİÇİMLERİ}

Reklamlar, kadın kimliğini, erkek egemen bakış temelinden sürekli yeniden üreten, toplumsal kontrolün bir aracı olarak işlemektedir. Reklamlarda genellikle iyi ev kadınları, mutlu anneler, fiziği düzgün genç kadınlar, bakımlı, güzel olarak sunulan ideal kadın imgelerine rastlanmaktadır. Ayrıca bağımsız, güvenli, çalışkan, heyecanlı, başarılı ve macera arayan yeni kadın imgeleri de reklamlara yansımaya başlamıştır. Ancak, bu yeni kadın imgeleri de egemen bakışın etkisinden ve beğeniye sunulan bir arzu nesnesine dönüşme halinden uzak sunulamamakta, sunulduğunda ise erkeksileştirilerek ya da kimliksizleştirilerek sunulmaktadır (Karaca ve Papatya, 2011: 482).

Televizyon reklamlarında kadının anneliği, çocuklarına bakması, iyi bir ev kadını olması, başarılı bir iş yaşamının yanı sıra kusursuz bir eş, kadınlığı, çekici bir vücuda sahip olması, cinsellik açısından özellikle vurgulanan bacakları, bakımlı saçları, elleri, yüzü, teni, belli bir mal ya da hizmeti satmak için reklamcılar tarafından yoğun olarak kullanılmaktadır (Özgür, 1996: 238).

Kadınlar reklamlarda çoğunlukla fiziksel yönden çekici ve bakımlı olarak izleyiciye sunulmaktadirlar. Gazete, dergi ya da televizyon reklamlarında kadınların cinsel objeler olarak sunulmaları, bir bakıma onları erkek cinsel arzusunun objesi haline getirmektedir. Reklam stratejileri kadınların iyi bir eş ve anne rolüne uygun olarak oluşturulmaktadır. Günümüzde kadınların çalışma hayatlarında daha yoğun

\section{| GAZIOSMANPAŞA ÜNIVERSİTESİ SOSYAL BİLIMLER ARAŞTIRMALARI DERGİSİ}


olarak yer almasıyla birlikte reklamlarda yer verilen kadın olgusu da değişime uğramıştır. Reklamların yeni kadın tipi iyi bir eş ve anne olmanın yanı sıra iş yaşamında başarılı kariyer sahibi bir kadındır (Büyükbaykal, 2011: 25). Tüm bu söylenenler ışı̆̆ında reklamlarda kadına çeşitli roller verilmektedir.

\section{A. DEKORATIF NESNE ROLÜNDEKİ KADINLAR (SEKSİ/BAKIMLI/ FORMDA KADIN)}

Reklamlarda dekor öznesi olarak kullanılan kadın iki şekilde gösterilir. Birincisi fiziksel çekiciliği olan kadınlar ki bunlar, gençlik, güzellik ve fiziksel çekiciliğin peşinde olan kadınlardır. İkinci ise cinsel obje olarak gösterilen ve ürün tanıtımında bedeni sergilenen kadınlardır. Bu tür reklamlarda kadınlar genellikle cinsel çekicilik, seksi gösterimler ve seksüel ifadeler kullanılarak gösterilir. Reklamcılar, kadınları sıklıkla bu kategoride kullanır ve bir cinsel obje olarak gösterirler. Tanıtımı tapılan ürünün pazarlanması, satılması veya hedef kitleye daha iyi bir şekilde sunulması için kadınlar, bir askı, bir paket veya raf görevi görürler (Türkoğlu ve Alayoğlu, 2009: 516517).

Kadını erkekten ayıran en önemli özelliği dişiliğidir. Reklamcılar kadının bu özelliğini, mal ya da hizmetlerin satışlarını artırmak amacıyla reklam filmlerinde kullanarak değerlendirmişlerdir. Reklamlarda öncelik tüketicinin dikkatini ve izlenmeyi sağlamak olunca kadın cinselliği reklamlar için vazgeçilmez bir unsur haline gelmiştir (Şimşek, 2006: 84).

Reklamlarda temizlik ve vücut bakım ürünlerini kullananlar genellikle kadınlardır. Bunun arkasında genellikle iki neden bulunmaktadır: reklamcların hedef tüketici kitlesi genellikle alışveriş işinden sorumlu görülen kadınlardır. Bundan ötürü reklamlardaki karakterler kadındır. Böylece medyada üretici olarak ev işi dışındaki ücretli işlerde çalıştı̆̆ pekiştirilmektedir. Reklamlarda bu ürünleri kullananların kadın olarak sunulması aynı zamanda yine kadın bedeninin sergilenmesine neden olmaktadır. Böylece kadın bedeni erkek bakışına sunulurken bir yandan da kadınlar kendilerine ideal kadın (canlı, sağlıklı, formda, doğal) nitelikleri kazandıracak ürünü seçmeye yönelir (Binark ve Bek, 2010: 163-164).

\section{B. BAĞIMSIZ ROLDEKİ KADINLAR ( SÜPER/ZEKİ/KENDİNE YETEN KADIN)}




\section{| ÖMER BÜSTAN}

$\mathrm{Bu}$ rolde gösterilen kadın, eğitimli, modern, kentli, zeki, özgür, özgüveni yüksek, güzel, başarılı, hem ev hem de iş yerindeki işleri yapan iyi bir eş ve anne rolünü sergileyen bağımsız ve kendine güveni tam olarak karşımıza çıkmakta ve günlük hayatta bütün problemleri çözebilen her şeyin üstesinden gelen ne istediğini bilen kadınlardır. Kısacası bu tür reklamlarda kadın kendi başına yaşayabilen ve kendine yeten kadın olarak gösterilmektedir. Ayrıca bu rol şeklinde kadınlar, erkeğin yerini alabilir ve erkeğe hiçbir konuda ihtiyaç duymazlar.

Reklamcılar tarafından kadınlar öncelikle reklamın hedef kitlesi olmalarından dolayı daha sonra da başkalarını etkilemek ve ikna etmek için kullanılmaktadır. Her iki durumda da kadınlar yönetici, ev hanımı, çalışan kadın eş, anne veya anneanne olarak görüntülenmektedir. Günümüzde kadınlar toplum içindeki statülerindeki değişiklik nedeniyle yalnızca ev hanımı olarak değil, sorumluluk sahibi çalışarak evine bakan; bir bankac1, yönetici, diş doktoru, hemşire, mühendis, gibi konumlarda da görüntülenmektedir. Reklamlarda boy gösteren meslek kadınları tipleri daha çok sevgi ve şefkat göstermeyi gerektiren mesleklerde gösterilmektedir. Anlaşılacağ1 üzere kadın, hem dişiliği hem de sevgi ve şefkat özellikleriyle reklamcıların kullandığı bir metadır (Şimşek, 2006: 85).

\section{GELENEKSEL ROLLERDEKİ KADINLAR (ANNE/EŞ/EV KADINI)}

$\mathrm{Bu}$ kategorideki kadınlar, erkeğin korumasına ihtiyacı olan, önemli olmayan kararlar veren, güvence ihtiyacı hisseden rollerde genellikle de anne ve ev kadını olarak gösterilmektedir. Ev kadını olarak gösterilen kadın, erkeklere güvenir ve erkeklerde kadınları başlıca cinsel obje olarak görür. Kadın, erkeği memnun etmek için elinden gelen her şeyi yapmalı imajı verilir. Kadının ev kadını rollerinden dolayı reklamlarda aileye ilişkin ürünlerin tanıtımında kadınlar kullanılmaktadır. Bu tür ürünlerin (gıda, temizlik, giyim vb.) reklamlarında gösterilen kadının, ev içindeki görevlerini kolay, hızlı ve en iyi şekilde yaptığı gösterilmektedir. Böylece hedef kitle olan tüketiciler de reklamlardaki kadın imajına özenerek ürünü satın almaktadırlar (Türkoğlu ve Alayoğlu, 2009: 516).

Kadın, reklamlarda çocuklarının ve erkeğin üstüne titreyip yemek hazırlarken, servis yaparken görüntülenir ve böylece kadının toplumsal rolü pekiştirilir. Genelde reklamlardaki ev hanımları temizlik takıntılıdırlar. Kendi kendilerine temizlik ürünleri hakkında konuşur, iyi yıkanmamış bir gömlekten dolayı üzüntü çekerler, çünkü daha

\section{| GAZIOSMANPAŞA ÜNIVERSITESİ SOSYAL BİLIMLER ARAŞTIRMALARI DERGİSİ}


iyi bir anne, daha iyi bir eş olabilmenin peşindedirler. Medyada kadının anne ve eş olarak rolü üç biçimde karsımıza çıkmaktadır. Bunlar; temizlik, yemek ve çocuk bakımıdır. Anne ve eş olarak yer alan kadınlar güzel, bakımlı, saçları yapılı, sağlıklı ve formdadır. Giysileri genellikle beyaz renkte ve şıktır. Bu kadınların yerleştirildiği mekânlar çoğunlukla mutfak, banyo ve alışveriş merkezidir. Kadınlar ev isi yapmaktan dolayı memnun, huzurlu ve tatminkârdırlar (Çolakoğlu, 2011: 77-78).

Özellikle televizyon reklamlarında iyi bir eş ve anne rolünde izleyiciye sunulan kadın imgesi ile kadınların 'ev hanımı' rolü vurgulanmaktadır. Reklamların toplumsal yapıdaki değişimle birlikte değişime uğradığı bir gerçektir. Yani değişen değerler, beklentiler ve yaşam tarzları reklamların yeniden kurgulanmasına yol açmaktadır. Reklamlar toplumsal gerçekliğin temsil edilmesinde son derece önemli bir role sahiptir. Bir bakıma toplumsal gerçekliğin reklamlarda sunulduğunu söylemek mümkündür.

Reklamlarda kadınların rolleri de bir anlamda toplumsal gerçekliğe bağlı olarak sunulmaktadır. Son yıllarda kadınların daha fazla iş yaşamında kendilerini göstermeleriyle birlikte çalışan kadının da yer aldığı reklamlara medyada yer verilmektedir. Kadın iş yaşamında ne derecede yer alırsa alsın anne ve eş rolleri de reklamlarda vurgulanmaktadır (Büyükbaykal, 2011: 25).

Reklamlarda kullanılan kadınlar, ister dekor malzemesi olarak, ister anne ve eş olarak kullanılsın, hep güzel, çekici, genç ve bakımlı görünmektedirler. Bu yolla reklamlar, kadınların hiçbir zaman ulaşamayacakları "ideal ben" egolarına seslenmekte ve kadınlarda güvensizlikler oluşturmaya çalışmaktadır (Demir, 2006: 294).

\section{DETERJAN REKLAMLARINDA GELENEKSEL KADIN TIIPLEMESİ}

Televizyon reklamlarının bireylere ulaşması diğer iletişim araçlarına nazaran daha yaygındır. Örneğin dergi, gazete bugün her haneye giremezken televizyon basılı medyanın başaramadığını başarmıştır. Televizyon reklamları da bu nedenle önemli bir pazarlama aracı olmuştur. Markaların, firmaların bir ürünü reklamlar aracılığıla halka sunması ve beraberinde gelen reklam ürünlerinin çeşitlilik kazanması ile pazarlanmaya çalışılan ürünün sunumunda o ürüne cinsiyet kazandırma çabası vardır.

Bir deterjan reklamında sadece kadınların yer alması toplum üzerinde güçlü bir etki bırakmaktadır. Burada kazandırılmak istenen düşünce ise sadece kadınların çamaşır yıkayabileceği ya da çamaşır yıkamanın kadınların yapacağı bir iş 


\section{| ÖMER BÜSTAN}

olmasıdır. Temizlik ürünü reklamlarındaki kadın genellikle anne ve eş olarak güzel, bakımlı, saçlar yapılı, sağlıklı ve formda olarak geleneksel rollerde sunulmaktadır. Kadınlar bu reklamlarda genellikle beyaz kıyafetler giyinmektedir ve mutfak, banyo ve tuvalette temizlik yaparken görüntülenerek temizliğin sadece kadın işi olduğu vurgusu yapilmaktadir.

$\mathrm{Bu}$ bağlamda çalışmamızda, farklı markalarda deterjan reklamlarına yer verilmiş ve kadının bu reklamlarda sunum biçimi ele alınmıştır.

\section{A. Ace Çamaşır Suyu Reklamı}

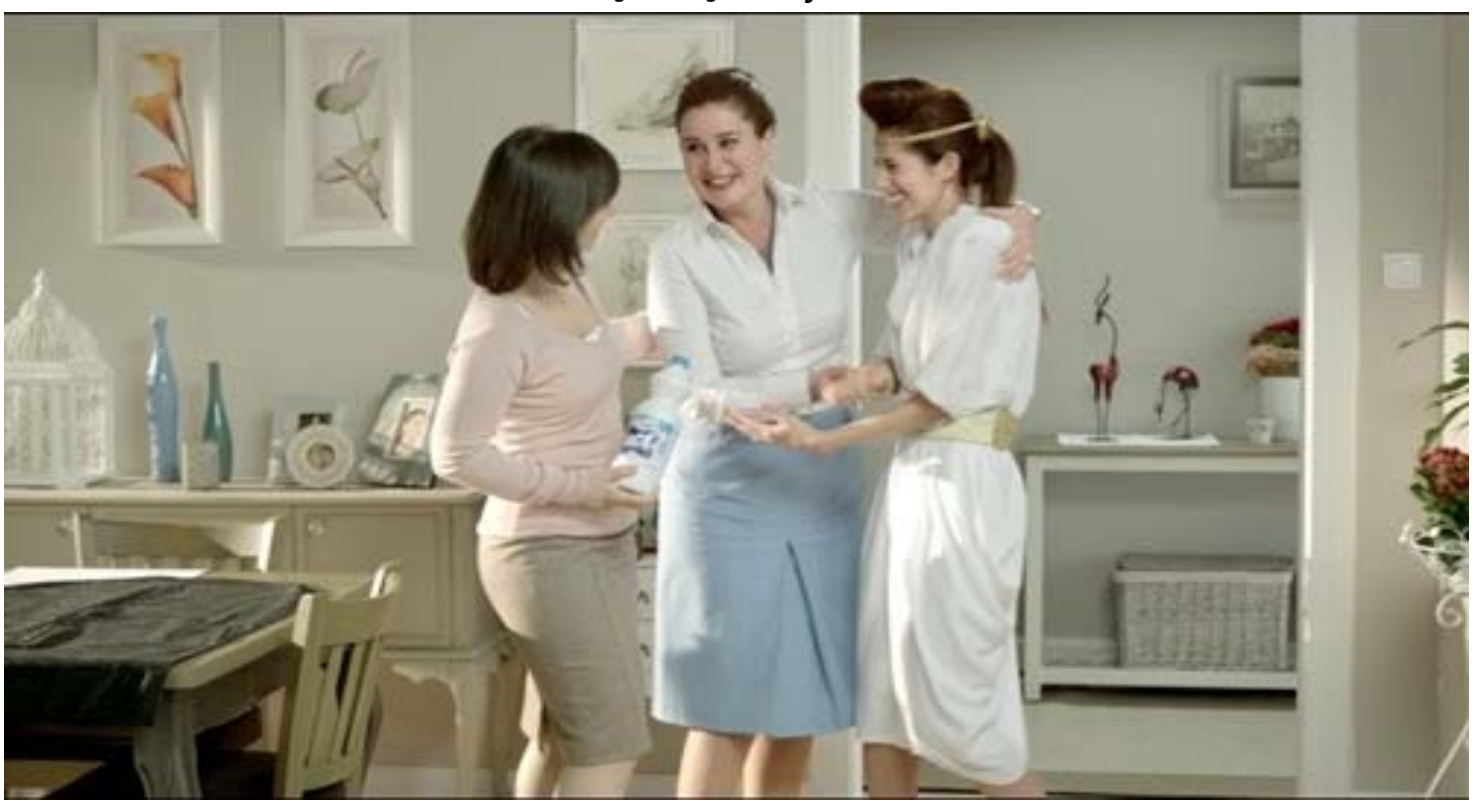

a) Anlati

Reklam, bir kızın odasında dolapta elbise aramasıyla başlar ve kız annesine seslenir, 'anne, akşam okulda 80'ler kıyafet balosu var'. Anne, ise bu arada gelen arkadaşına salonda çay sunmakta ve aynı zamanda kızının bu sözüne karşılık "eee" demektedir. Kızı ise annesine, 'giyecek bir şey bulamıyorum der. Tam bu sırada annenin arkadaşı; 'benimkinin de derdi aynı ama benim eskilerim hep yıpranmış der' ve bu arada kız salona girerek elindeki elbiseyi annesine gösterip 'bu yeterince 80'ler mi diye sorar'. Anne yerinden kalkarak 'dur bakalım ben sana gerçek 80'leri göstereyim der' ve bir elbise çıkarıp kızına verir. Kız elbiseyi alıp odasına giderken 
annenin arkadaşı şöyle der; ' bu bizim mezuniyet balomuzda giydiğin elbise değil mi? Nasıl sakladın.' Kızın annesi işe şu cevabı verir;' 20 yıldır ACE var' diyerek Ace Çamaşır Suyunu gösterir. Bu sırada kız annesinin elbisesini giymiş ve çok neşeli bir halde salona gelir. Ardından reklamda kullanılan dış ses 'Ace Çamaşır Suyu ile beyazlarınız yıllara meydan okur' der ve reklam biter.

\section{b) Cinsiyetçi İçerik}

$\mathrm{Bu}$ reklam metninde, ürünün tanıtımı geleneksel aile imgesi kullanılarak yapılmaktadır. Reklamın hedef kitlesi ev hanımlarıdır. Öyle ki geçmişte aynı okulda arkadaş olan iki kadın artık birer ev hanımı, anne olarak gösterilmiştir. Geleneksel aile yapısını yansıtan reklamda kadınlar oturmuş çay içerken görüntüleniyor. Kendi elbisesini yıllarca saklayan sorumluluk sahibi titiz bir anne rolünü canlandırmıştır.

Bu reklamlarda, ürünün güven duyularak kullanılabileceği ve diğer ürünlerden farklı olduğunun tüketiciye kabul ettirilebilmesi için dış ses olarak erkek kullanılmıştır. Çünkü 'erkek güven vericidir, kadın ise erkeğe muhtaçtır' düşüncesi vurgulanmaya çalışılmıştır. Ayrıca misafir olarak gelen arkadaşının 'nasıl sakladın' sorusuna cevaben verilen 20 yıl sözü, kadının 20 yıldır aynı çamaşır suyunu kullandığını ve çamaşır yıkama işini kendisinin yaptığını göstermekte ve kullanılan deterjanı arkadaşına tavsiye edecek kadar memnun kaldığına vurgu yapılmaktadır.

\section{B. ABC Yumuşatıcı Reklamı}

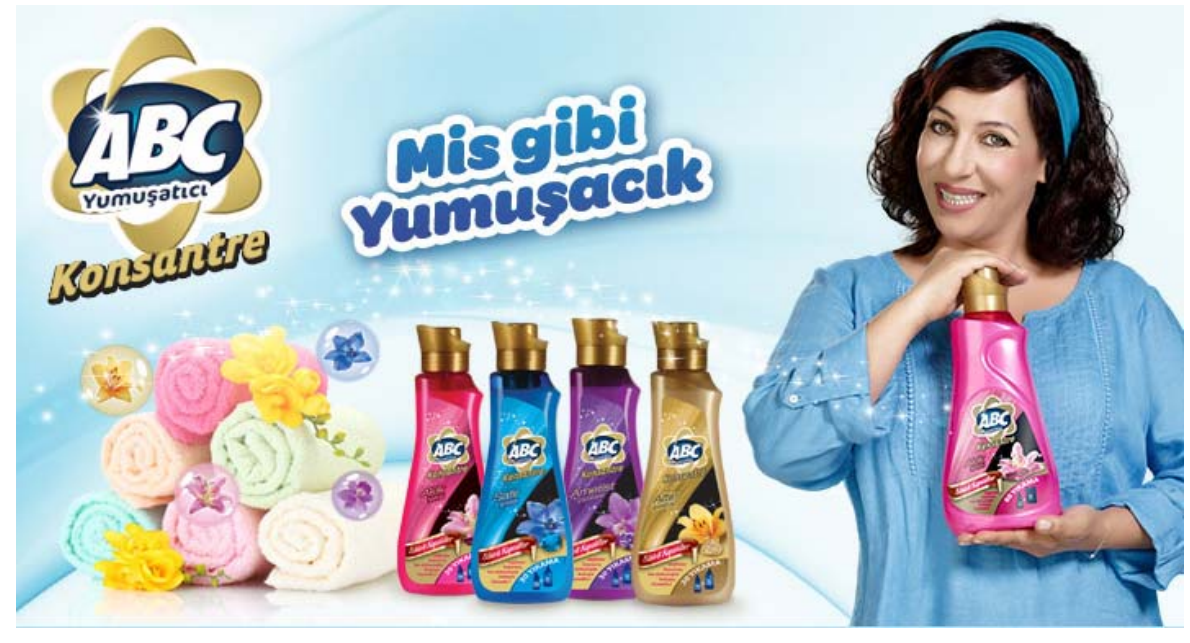




\section{| ÖMER BÜSTAN}

\section{a) Anlati}

Reklam, kadının elinde bir tabak pastayla salona girmesi ve kanepeye oturmasıyla başlar ve ardından kadın şöyle der; ' Bizde misafir çok önemlidir. Pastasıyd1, böreğiydi tüm hünerler sergilenir. Misafir banyoya giderken de arkasında seslenilir, canım bak orda havlu var sana çıkardım. Misafir havlusudur o. Emek çoktur o havluda. Bursa'dan alınır, dantel çekilir, yumuşatıcının en hasıyla yıkanır, sırf şunu duymak için; kızzz bu havluları nasıl böyle yumuşacık yaptın, mis gibi parfüm kokuyor hala. Ve şöyle devam eder. 'Sizi bilmem ama hanımlar ben bu sözü sık sık duyuyorum. Çünkü yumuşatmanın abc'sini biliyorum'. Ardından dış ses 'ABC Yumuşatıcı, günlerce mis gibi parfüm kokan yumuşacık çamaşırlar'. der ve reklam biter.

\section{b) Cinsiyetçi İçerik}

Reklamda yine geleneksel kadın imgesi kullanılmıştır. Elinde pastayla salona giren kadın havlularını hangi yumuşatıcı kullanarak yumuşattığını vurgulamakta ve misafirlerden aldığı olumlu tepkilerden de oldukça memnun olduğunu dile getirmektedir. Reklamda hem mutfak işlerinin hem çamaşır yıkama işlerinin hem de diğer ev işlerinin kadınların işi olduğu izlenimi verilmekle beraber kullanılan dış sesin yine erkek olması erkek egemen bir toplumun göstergesi şeklindedir.

Ayrıca dış ses olarak erkeğin kullanılması tanıtımı yapılan ürünün erkek onayından geçtiğini göstermekte, eğer erkeğin beğenisinden geçtiyse güvenilir bir üründür imajı verilmektedir. Başka bir ifadeyle erkek egemen söylemde kadının iyi bir ev hanımı olması şeklinde kullanılan dış ses kadını bu şekilde onaylamaktadır.

\section{Kosla Vanish Tül Reklamı}

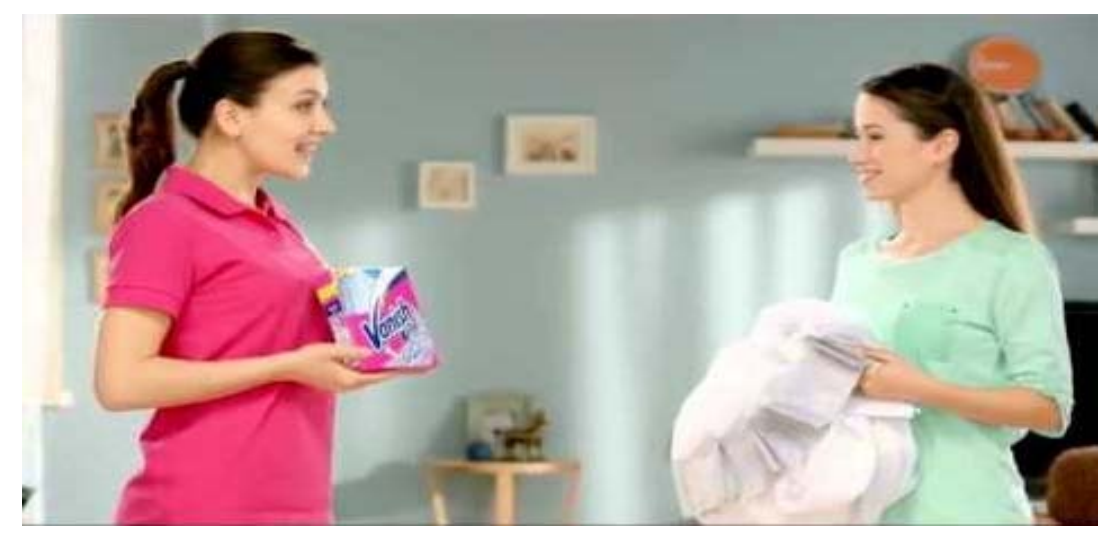




\section{a) Anlati}

Reklam farklı kadınların ellerinde kirlenmiş perdeler ve bu kadınların perdelere bakarak duydukları hoşnutsuzluğu 'aaa' 'bıktım' diye dile getirmeleriyle başlar. Ardından fotoğrafta görünen sağdaki kadın şöyle der; ' üst katlar iki kat daha fazla kirleniyor'. Sonrasında ise soldaki kadın devreye girerek, 'yeni iki kat beyazlatıcılı Vanish Kosla Tül kullanın, tepeden tırnağa gerçek beyazlıkla tanışın. Deterjanınız tüllerinizi beyazlatmaya yetmez oysa yeni Vanish tülün geliştirilmiş iki kat beyazlatıcı formülü perdelerinizi daha da beyaz yapar. Üst kısımlarını bile' der. Sonrasında perdelerini belirtilen marka deterjanla yıkayan kadının rahat bir şekilde kahvesini içtiği görüntülenir ve böylece reklam biter.

\section{b) Cinsiyetçi İçerik}

Ev kadınlarının kullanıldığı reklamda kadınlar perdelerinin kirlenmesinden dert yanmaktadır. Reklamda işlenen ev kadını figürü, kadının toplumsal rolünü tanımlamakta ve ev işlerinin salt kadının görevleri arasında yer aldığı mesajını kitlelere iletmektedir. Reklamda kadınların çamaşır makinesinden çıkan perdeleri görünce üzülerek 'bıktım' demesi ise çamaşır yıkamanın yalnızca kadın işi olduğunu göstermekte ve toplumsal cinsiyet eşitliği bu manada etkisiz kalmaktadır. Başka bir ifadeyle reklamda, perdelerin kirlenmesinin yalnızca kadınları rahatsız ettiği erkeklerin bu gibi işlerle hiç ilgisinin olmadığı anlatılarak geleneksel aile yapısındaki kadının sunumu hedef kitleye veya topluma yansıtılmak istenmiştir.

\section{Persil ColdZyme Reklamı}

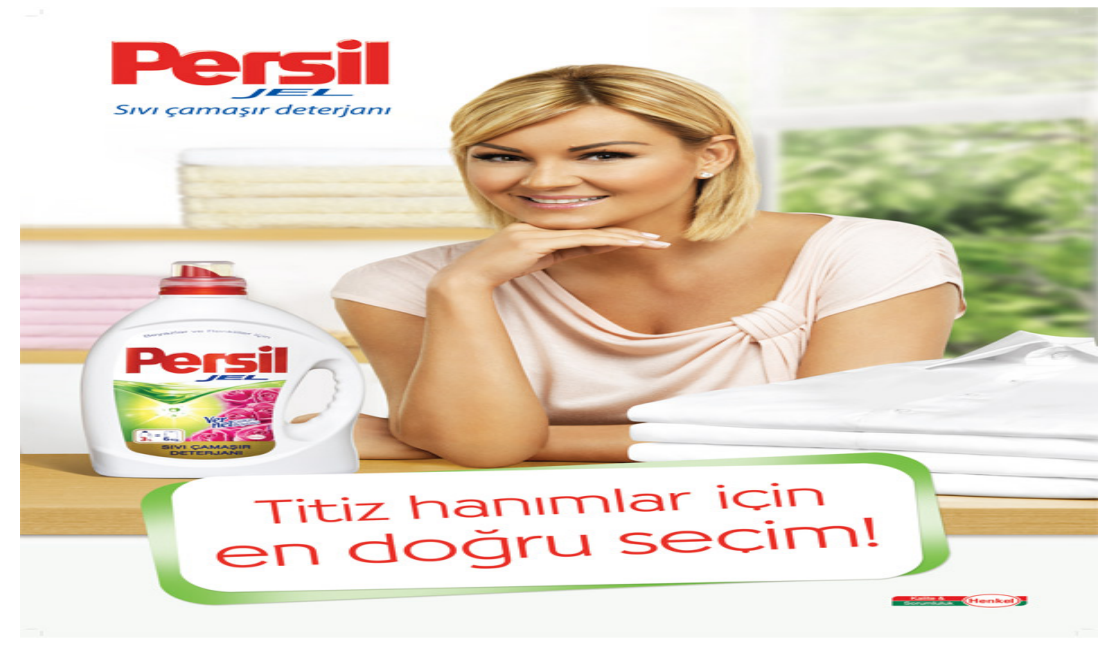




\section{| ÖMER BÜSTAN}

\section{a) Anlati}

Reklam Pınar Altuğ'un komşusu rolündeki bir kadının yine Pınar Altuğ'un kapı zilini çalması ve toz deterjanım bitti demesiyle başlar. Sonrasında Pınar Altuğ 'toz mu boş ver tozu yeni Persil Jeli denesene' der ve diğer kadın ise 'zor lekeleri de çıkarıyor mu' der ardından Pınar Altuğ çocuğunun gömleğinde lekeyi göstererek 'bizimkinin çikolata lekesi gibi mi' demesiyle devam eder. Diğer kadın ise 'benim toz deterjanım bile çıkaramaz bunu' der. Pınar Altuğ ise 'yeni Persil Jel çıkarır. ColdZyme formülünün enzimleri soğuk suda aktifleşir ve lekeleri sıradan toz deterjanlardan daha iyi çıkarır. Düşük ısıda bile'. Diğer kadın ise eline aldığı Persil Jeli göstererek 'bundan böyle sadece Persil Jel' der. Son olarak Pınar Altuğ ise Persil: 'biz titiz hanımların tercihi' demesiyle reklam biter.

\section{b) Cinsiyetçi İçerik}

Reklamda, diğer reklamlarda olduğu gibi yine kadınlar kullanılmıştır. Çünkü ürünün hitap ettiği kesim olarak kadınlar görülmektedir. Özellikle reklamda toplumun hemen hemen her kesimi tarafından tanınan bir kadının kullanılması da tanıtımı yapılan ürünün daha iyi pazarlanması amacı gütmektedir. Reklam incelendiği zaman kadının 'toz deterjanım' bitti demesi kadınla deterjanı özdeşleştirmektedir. Diğer bir ifadeyle bu söz, deterjan kullanmanın sadece kadınlara özgü bir nitelik olduğunu belirtmekte ve her firsatta toplumsal cinsiyetten bahseden medyanın bu ve bunun gibi reklamlar aracılığla aslında cinsiyet eşitsizliğine neden olduğu görülmektedir. Reklamda göze çarpan diğer bir unsur ise reklamın sonunda kullanılan 'Persil; biz titiz hanımların tercihi' sözüdür. Temizliğin, titizliğin yine aynı şekilde kadına atfedilmesi kadına yüklenen; temizlik yapma, çamaşır ve bulaşık yıkama gibi görevlerin toplum tarafından onaylanmasına neden olmaktadır.

\section{E. Cillit Bang Reklamı}

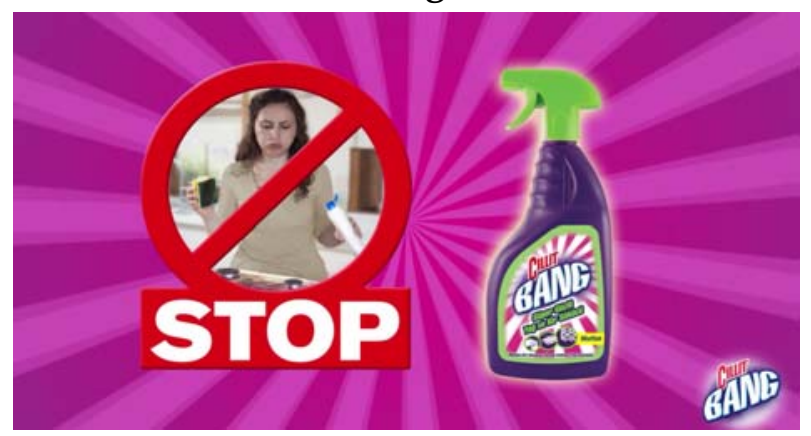

| GAZIOSMANPAŞA ÜNIVERSITTESİ SOSYAL BİLIMLER ARAŞTIRMALARI DERGİSİ 


\section{a) Anlat1}

Reklam, kadının ocağın üstünde kalıntı haline gelmiş yağ lekelerini ovalamasının görüntülenmesiyle başlar. Ardından kadın 'ovalıyorum ovalıyorum çıkmıyor demeye başlar ve kadın bu sözü defalarca tekrar eder sonunda ise of' diyerek elindeki süngeri fırlatır. Ardından dış ses (dış ses yine erkektir) devreye girerek 'oflamaya da ovalamaya da stop, sonunda Türkiye ovalamada parlatacak, yağ çözücü yeşil Cillit Bang'le yanmış yağları ve kirleri ovalamaya stop. Sizde Cillit Bang'i deneyin, ovalamaya stop deyin' der ve reklam biter.

\section{b) Cinsiyetçi İçerik}

Reklamda yine temizlik işlerinden sorumlu olarak görülen kadın kullanılmıştır. Öyle ki kadın mutfakta o kadar temizlik yapmış ki artık bıktığını ifade eden bir üslupla 'of' demekte ve elinde bulunan bulaşık süngerini fırlatmaktadır. Bu reklamda da diğer reklamlarda olduğu gibi kadın ev hanımı rolünde görüntülenmekte; kadının yeri evidir ve evinde de temizlik işlerinden sorumludur imaj1 yansıtılmak istenmiştir. Yine aynı şekilde reklamda dış ses olarak erkeğin kullanılması ve kadının temizlik yaparken görüntülenmesi temizliğin sadece kadınları rahatsız ettiği, erkeklerin ise ancak ürün tavsiyesinde bulunacağı gibi bir düşünce topluma yansıtılmaya çalışılmıştır.

\section{F. Pril Gold Reklamı}

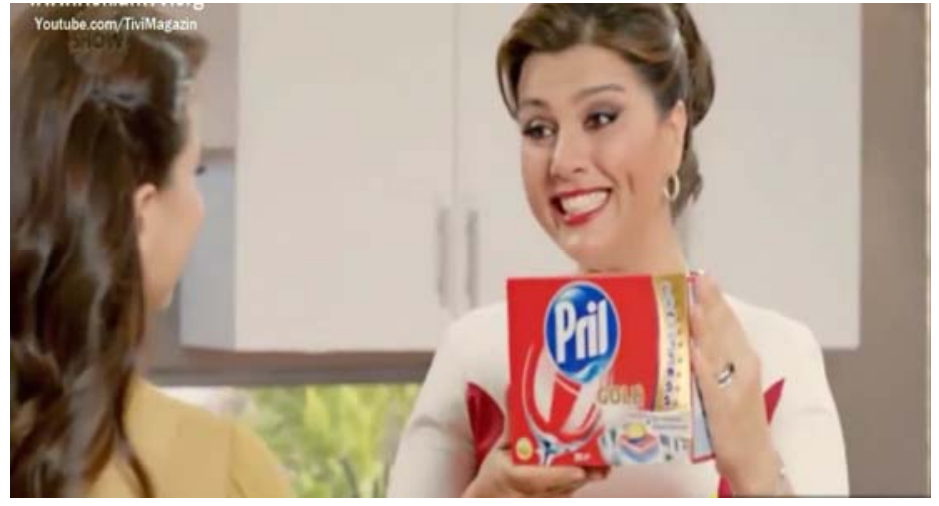

\section{a) Anlatı}

Dört kadının sofrada yemek yerken görüntülenmesiyle başlayan reklam, kadınlardan birinin ev sahibi rolündeki kadına, 'fırında makarnan harika demesiyle' devam eder. Fotoğrafta görünen ve ev sahibi rolünde olan kadın ise, 'afiyetler olsun' der ve sofrayı toplamaya başlar. Kadınlardan biri ise ev sahibine yardımcı olur ve 'yemeklerine bayıldık' der ve devam eder; 'Ne kadar lezzetliyse yıkaması da o kadar 


\section{| ÖMER BÜSTAN}

zor, bu kirler için ön yıkama şart'. Ev sahibi rolünde kadın ise 'Yeni Pril Goldla değil' der. Ardından diğer kadın da 'ön yıkama etkili mi'? diye sorar. Sonrasında ev sahibi olan kadın: 'evet bulaşık makinesine öylesine koyuyorum. Pril Gold mükemmel temizlik için kirlere derinlemesine işler ve kolayca temizler' der ve diğer kadın ise 'Pril bir harika, aynı yemeklerin gibi' demesiyle devam eder. Son olarak ev sahibi rolündeki kadın, 'hamarat hanımlar Prille ışıldar' der ve reklam biter.

\section{b) Cinsiyetçi İçerik}

Reklamda kadınlar yemek yerken görüntülenmekte ve sıra bulaşık yıkamaya geldiğinde diğer bir kadının bulaşık yıkamanın kadınlara özgü bir iş olduğunu, 'yemekler ne kadar lezzetliyse bulaşıklar yıkamanın da o kadar zor olduğunu' dile getirmesi aslında bütün durumu özetler niteliktedir. Kadının bu sözü toplumsal cinsiyet rolleri bağlamında kadına yüklenen rollerin neler olduğu göstermekte ve bu durum da reklam aracılığla hedef kitle olana kadınlara yansıtılmak istenmiştir. Kaldı ki yine reklam ana karakterinin 'hamarat kadınlar Prille ışıldar' demesi hem yemek yapmanın hem de yine aynı şekilde bulaşık yıkmanın kadın işi olduğunu, kadın tarafından onaylatmakta ve topluma 'kadın imajı'nın nasıl olması gerektiği mesajını vermektedir. Reklamda göze çarpan diğer bir cinsiyetçi söylem ise bir kadının 'yemeklerin bir harika' demesi. Başka bir ifadeyle yemek yapmanın bir kadın görevi olduğu ve bu görevi de hakkıyla yerine getirdiği bu sözle anlatılmak istenmiştir.

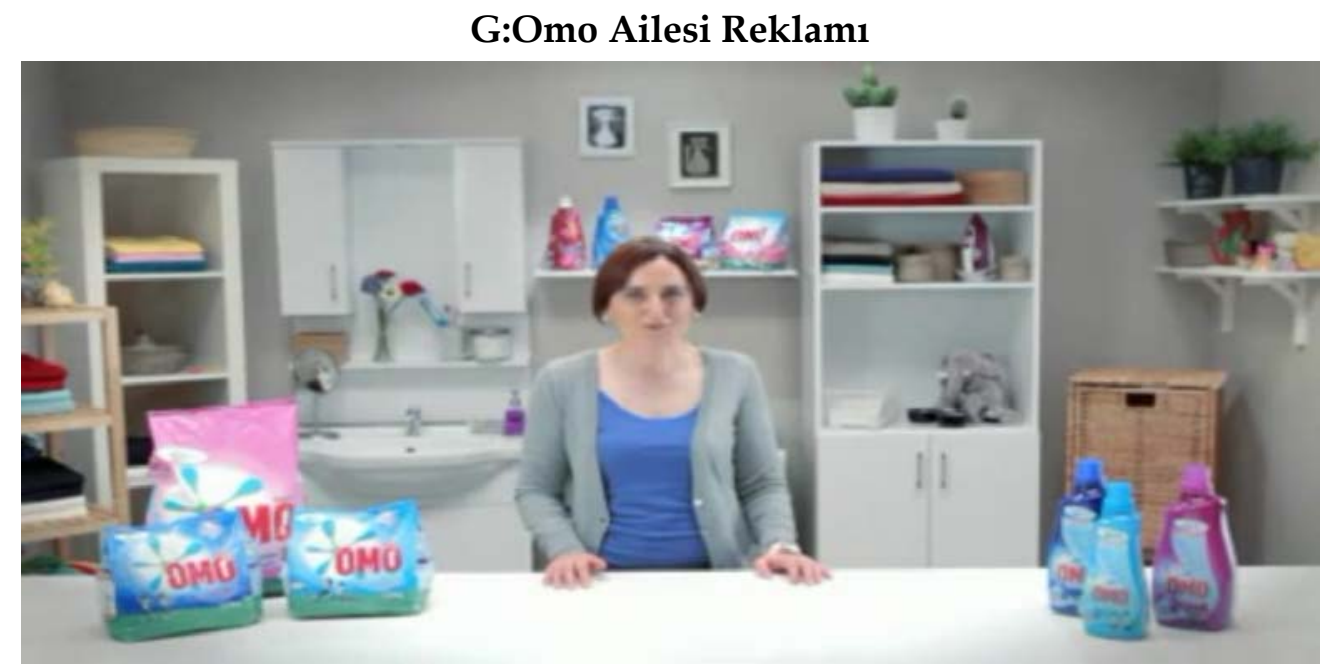




\section{a) Anlati}

Reklam fotoğrafta görünen kadının 'merhaba hanımlar' demesiyle başlar. Ardından devam eder. 'Omo ailesi her türlü yıkama programında ve sicaklıkta tüm çamaşırlarınız için üstün temizlik ve beyazlık sağlarken sizlere farklı koku seçenekleri de sunar'. Soldaki toz deterjanları göstererek 'toz deterjanlarımızın yanı sıra omo sizlere yepyeni ultra konsantre sıvı deterjan serisi de sunuyor. Omo sıvı deterjan aynı miktardaki toz deterjanlara göre 4 kat daha fazla çamaşır yıkamanızı sağlar. Omo aktif ferahlatıcı parfümü ile sizlere benzersiz beyazlık ve temizlik sunar. Omo aktif fresh sizlere çiçek esanslarının birleşiminden olan eşsiz bir ferahlık sağlar. Son olarak omo color ise renkli çamaşırlarınıza özel olarak solmalarına engel olan formülü ile güçlü bir temizlik elde etmenize yardımcı olur'. der ve reklamı bitirir.

\section{b) Cinsiyetçi İçerik}

Reklamda ürünün tanıtımı görevi yine bir kadın tarafından verilmekle beraber daha reklamin ilk başında 'merhaba hanımlar' demesi cinsiyetçi söylemin ilk işareti olarak karşımıza çıkıyor. Ayrıca yapılan bu vurgu reklamın hedef kitlesinin cinsiyetini de ortaya koymaktadır. Tanıtımı yapılan üründe kadın, mekân olarak banyoda gösterilmekte aslında yine topluma bazı mesajlar verilmektedir. Başka bir ifadeyle banyoda gösterilen kadın, gerek kendi cinsine gerekse karşı cinsi olan erkeklere kendi yerini ve duruşunu göstermekte ve yukarıdaki reklam örneklerinde de üstünde durduğumuz cinsiyet eşitsizliğin toplumdaki yansımasını gözler önüne sermektedir. Ayrıca reklamda dikkat edilmesi gereken diğer bir nokta ise ürün tanıtımını yapan kadının bir ev kadını imajı verilerek gösterilmesi ve bu sayede erkek egemen toplum yapısının bir bakıma onaylanmasıdır. Göze çarpan diğer bir cinsiyetçi söylem ise kadının sürekli 'çamaşırlarınız' diyerek kadınla çamaşır yıkamayı özdeşleştirmesidir. Diğer yandan arka planda gayet temiz bir banyo, her şeyin yerli yerinde olduğu dolaplar da aslında kadının toplumsal rolleri bağlamında değerlendirilirse temizliğin, düzenliliğin ve titizliğin sadece kadın işi olduğunu vurgular niteliktedir.

\section{SONUÇ ve DEĞERLENDİRME}

Reklamların tüketiciye verdiği mesaj, ürünün tam onların istediği gibi bir ürün olduğunu hissetmelerini sağlamaktır. Öyle ki bazen tüketiciler reklamların etkisine öyle kapılmaktadırlar ki ihtiyaçları olmasa bile birçok ürünü reklamlarından etkilendikleri için satın alabilmektedirler. 


\section{| ÖMER BÜSTAN}

Reklamin asıl hedefinin ürünü sattırmak olduğu bilinen bir gerçektir. Özellikle dijital olanakların böylesine zenginleşip çeşitlendiği bir ortamda reklamcıların, kadının çekiciliğinden yararlanarak mal ve hizmetle birlikte kadını da bir "emtia" gibi kullanmaktan hiçbir zaman vazgeçmeyecekleri de söylenebilir (Nakilcioğlu,2015). ABD’li ünlü bir görsel sanatçı (White, 2000), "Nerede cinsellik ve teknoloji varsa orada satış vardır." diyor.

Reklamcılar, kadının güzelliği ve cinselliğini gerekli gereksiz hatta dekor malzemesi olarak kullanırken, farkında olmadan veya bilerek kadının toplumdaki ikincil rolünü pekiştirmektedirler. Genellikle genç ve güzel kadınlar kullanarak kadınların bilinçaltındaki korku ve güvensizliklerini arttırmakta, ayrıca hep anne, eş, ev kadını gibi göstererek kadınlara ev içi alanda kalarak doğrusunu yaptıkları mesajını vermektedirler. Çalışan kadınları ise daha az göstererek, onlara; çalışarak evlerini, çocuklarını, eşlerini ihmal ettiklerini hatırlatarak bütün kadınların onlar gibi olmadığını (ev kadınlığını kabul ettiğini) vurgulamaktadırlar. TV reklamlarının, kadınları güzel, çekici, ama fazla zeki olmayan, erkeklerin kendini beğenmesi, lekeleri çıkarmak, iyi temizlik yapmak gibi konularda kaygılanan bireyler olarak göstermesi, erkek ve kız çocuklarını, cinsel rol modelleri konusunda yanlış bilinçlendirmektedir.

Reklamcılar yaratıcı zekâlarını kullanırken, insanları en zayıf yönlerinden vurmaya çalışmaktadırlar. Reklamcılar, kadının güzelliği ve cinselliğini gerekli gereksiz hatta dekor malzemesi olarak kullanırken, farkında olmadan veya bilerek kadının toplumdaki ikincil rolünü pekiştirmektedirler (Kula Demir 2006). Özellikle deterjan ve gıda reklamlarında kadının sadece ev alışverişinden ve evin temizliğinden sorumlu olduğu vurgusu yapılarak günümüz medyasında en çok tartışılan konulardan biri olan kadın-erkek eşitliği medyanın içine düştüğü çelişkiyi gözler önüne sermektedir.

Reklam metinlerinde kadının güzel, çekici görünümünden, cinsel kimliği ve rolünden önce; düşünen, üreten bir insan olarak ele alınması gerekmektedir. Kadın sorunları ve kadın hakları gibi spesifik problemler ihmal edilmektedir. Reklamlarda kadın unsurunun gerçek ve modern yaşamın gerisinde değil, önünde kullanılması gerekmektedir. 


\section{KAYNAKLAR}

Binark, M.; Bek, M.G. (2010), Eleştirel Medya Okuryazarlığı: Kuramsal Yaklaşımlar ve Uygulamalar. İstanbul: Kalkedon Yayınları.

Büyükbaykal, I.C. (2011), "Medyada Kadın Olgusu" [Elektronik Sürüm]. İstanbul Üniversitesi İletişim Fakültesi Hakemli Dergisi.(28).

Çolakoğlu, B.E. (2011), Reklamlarda Sosyal Temsil Alanı Olarak Yaşlı Kuşağın Sunumu. (Yayımlanmamış Doktora Tezi). İzmir: Ege Üniversitesi Sosyal Bilimler Enstitüsü.

Çolakoğlu, B.E.; Doğaner, M. (2008), “Televizyon reklamlarına toplumsal cinsiyetin yansımasi: Erkek analizi". Firat Üniversitesi Sosyal Bilimler Dergisi, 18(2), 333342.

Demir, N. K. (2006), “Kültürel Değişimlerin Reklamlarda Kadın Ve Erkek RolModellerine Yansıması", [Elektronik Versiyon]. Firat Üniversitesi Sosyal Bilimler Dergisi. 16(1), 285-304.

İmançer, D; İmançer, A. (2006), “Medya ve Kadın”. Dilek İmançer (Ed.). Televizyon Reklamlarında Kadın Sunumuna Özgü Klişeler (ss. 121-144). Ankara: Ebabil Yayıncilik.

Karaca, Y; Papatya, N. (2011), "Reklamlardaki Kadın İmgesi: Ulusal Televizyon Reklamlarına İlişkin Bir Değerlendirme". Süleyman Demirel Üniversitesi İktisadi ve İdari Bilimler Fakültesi Dergisi, 16 (3), 479-500.

Meral S. P. (2008), "Reklam, toplumsal cinsiyet kalıp yargıları ve iktidar". Civilacademy, 6(3), 17-29.

Şimşek, S. (2006), Reklam ve Geleneksel İmgeler. İstanbul: Nüve Kültür Merkezi Yayınları.

Türkoğlu, N.; Alayoğlu, S.T. (2009), Medya ve Kültür. İstanbul: Urban Kitap

Yılmaz, N. (2007), Televizyonda Yayımlanan Gida Reklamlarında Kadın İmgesinin İncelenmesi. (Yayınlanmamış Yükseklisans Tezi). Ankara: Ankara Üniversitesi Sosyal Bilimler Enstitüsü.

Yüksel, N.A. (2006), “Otomobil reklamlarında yerleşik toplumsal cinsiyet kalıpları: Türkiye'de yayınlanan televizyon reklamları üzerine bir çalışma". Selçuk İletişim, 4(2), 115-124. 